\title{
International Group for Research in the Immunopathogenesis of Genital Infections
}

\author{
III. International Symposium on \\ Heat Shock Proteins: \\ Expression, Immunity and Women's Health \\ April 10-11, 1999 \\ Weill Medical College of Cornell University \\ 1300 York Avenue at East 69th Street \\ New York, NewYork, USA
}

Scientific Program Committee Steven S. Witkin, PhD, New York, New York, USA Myriam Askienazy-Elbhar, $\mathrm{PhD}$, Paris, France William J. Ledger, MD, New York, New York, USA

Sponsors 


\section{SYMPOSIUM SCHEDULE}

\section{SATURDAY, APRIL 10, 1999}

\section{8:15-9:00 Registration Uris Auditorium \\ 9:00-9:10 Welcome Steven Witkin \\ 9:10-9:20 Greetings William J. Ledger \\ SESSION I. HEAT SHOCK PROTEIN EXPRESSION IN WOMEN WILLIAM J. LEDGER, CHAIRPERSON}

9:20-9:50 Heat Shock Protein Expression in Human Endometrium Throughout the Menstrual Cycle Siamak Tabibzadeh, Manhasset, New York, USA

9:50-10:20 Heat Shock Protein Expression During Gametogenesis and Embryogenesis Andreas Neuer, Dortmund, Germany

10:20-10:50 Induction of Heat Shock Protein Expression in Cervical Epithelial Cells by Human Semen Jan Jeremias, New York, New York, USA

10:50-11:20 COFFEE BREAK

11:20-11:35 Detection of Heat Shock Proteins and Heat Shock Protein Antibody Complexes in Placental Tissues Following Preterm or Term Birth and Intrauterine Growth Retardation Mathias Ziegert, Leipzig, Germany

11:35-11:50 Detection of the Human 70-kD And 60-kD Heat Shock Proteins in the Vagina: Relation to Microbial Flora, Vaginal pH, and Method of Contraception Paulo Giraldo, Campinas, Brazil

11:50-12:20 Heat Shock Proteins and Regulation of Cytokine Expression Stuart Calderwood, Boston, Massachusetts, USA

12:20-1:50 LUNCH

\section{SESSION II. CONSEQUENCES OF AUTOIMMUNITY TO HEAT SHOCK PROTEINS ZEV ROSENWAKS, CHAIRPERSON}

1:50-2:20 Persistent "Silent" Chlamydia trachomatis Female Genital Tract Infections Myriam Askienazy-Elbhar, Paris, France

2:20-2:50 Immunity to Heat Shock Proteins and Pregnancy Outcome Steven Witkin, New York, New York, USA

2:50-3:05 Presence of Anti-HSP60 Antibodies in the Seminal Fluid of Male Partners of Infertile Couples and its Relationship With Antisperm Antibodies Gladys Munoz, Caracas, Venezuela

3:05-3:35 Immunity to Heat Shock Proteins and Neurological Disorders of Women Gary Birnbaum, Minneapolis, Minnesota, USA

3:35-4:05 Immunity to Heat Shock Proteins and Arthritic Disorders Willem van Eden, Utrecht, The Netherlands

4:05-4:35 Heat Shock Proteins and Protection Against Ischemic Injury Wolfgang Dillmann, La Jolla, California, USA

4:35-4:50 Does Immune Response to Heat Shock Proteins in Periodontal Disease Influence Atherogenesis? Ingrid Glurich, Buffalo, New York, USA

4:50-5:05 Detection Of Chlamydia pneumoniae Reactive $\mathrm{T}$ Lymphocytes in Human Atherosclerotic Plaques of Carotid Artery

Jorma Paavonen, Helsinki, Finland 
SUNDAY, APRIL 11, 1999

\section{SESSION III. HEAT SHOCK PROTEIN EXPRESSION AND IMMUNITY IN GENITAL TRACT INFECTIONS JACK SOBEL, CHAIRPERSON}

9:00-9:30 Surface-Associated Heat Shock Proteins of Legionella pneumophila and Helicobacter pylori: Roles in Pathogenesis and Immunity Paul Hoffman, Halifax, Nova Scotia, Canada

9:30-9:45 Heat Shock Protein 60 Is Exposed on the Surface of Chlamydia pneumoniae Elementary Bodies Kirsi Laitinen, Finland

9:45-10:00 Novel Pathways Underlying Bordetella pertussis-Induced Apoptosis In Human Monocytes: Role of ATP, Mitochondria and Heat Shock Protein 70

Maria Bachelet, Paris, France

10:00-10:30 Chlamydial Heat Shock Proteins and Disease Pathology: New Paradigms for Old Problems? Gerald Byrne, Madison, Wisconsin, USA

10:30-11:00 Heat Shock Protein Expression and Immunity in Chlamydial Infections David Mabey, London, United Kingdom

\section{1:00-11:30 COFFEE BREAK}

11:30-11:40 Effect of Antigen Source on the Measurement of IgG Antibody Responses to the 60kDa Chlamydia Heat Shock Protein

Rosanna Peeling, Winnipeg, Manitoba, Canada

11:40-11:50 Humoral Immunologic Response to Chlamydia trachomatis 57kDa Heat Shock Protein in Female Mice With Chronic Urogenital Chlamydia trachomatis Infection

Maria Borrego, Lisbon, Portugal

11:50-12:00 Humoral Immune Response to Chlamydia trachomatis 60kDa Heat Shock Protein in Russian Women With Ectopic Pregnancies and Spontaneous Abortions

JM Sueur, Amiens, France

12:00-12:10 Reproductive Prognosis After Ectopic Pregnancy: Does Serologic Response to the Chlamydia Heat Shock Protein 60 Play a Role?

Istvan Sziller, Budapest, Hungary

12:10-12:20 Patterns of Seroreactivity to Chlamydia trachomatis HSP10, HSP60 and MOMP Among Women With Tubal Factor Infertility, Women With Active Infections, or Healthy Uninfected Women David LaVerda, Madison, Wisconsin, USA

12:20-12:30 Circulating Antibodies to Chlamydia trachomatis and the 10kDa and 60kDa Heat Shock Proteins in Women With Tubal Occlusion $+/-$ Hydrosalpinx

Steven Spandorfer, New York, New York, USA

12:30-2:00 LUNCH

\section{SESSION IV. THERAPEUTIC ASPECTS OF HEAT SHOCK PROTEINS JAMES MCGREGOR, CHAIRPERSON}

2:00-2:30 Heat Shock Protein-Based Therapeutic Strategies Against Human Immunodeficiency Virus Type I Infection Bluma Brenner, Montreal, Quebec, Canada

2:30-3:00 Characterization of Mild Whole-Body Hyperthermia Protocols Using Human Breast, Ovarian, and Colon Tumors in Severe Combined Immunodeficient Mice Elizabeth Repasky, Buffalo, New York, USA 
3:00-3:30 Surgical Stress and the Heat Shock Response George Perdizet, Hartfort, Connecticut, USA

3:30-4:00 Heat Shock Proteins and Cancer Immunotherapy Sreyashi Basu, Farmington, Connecticut, USA

4:00-4:10 Circulating Antibodies to Heat Shock Proteins in Sera of Women With Gynecological Cancers Irina Korneeva, New York, New York, USA

4:10-4:20 Fever-Range Hyperthermia Stimulates Lymphocyte Adhesion to Intra-Tumoral Vessels in Models for Murine and Human Mammary Adenocarcinima Sharon Evans, Buffalo, New York, USA

4:20-4:30 Lipopolysaccharide-Mimetic, Ips Gene-Dependent Effects of Taxol Mediated by a Heat Shock Protein

Cynthia Byrd, New York, New York, USA

4:30-4:40 Selective Membrane-Associated and Cytosolic Expression of Heat Shock Protein 70 in Rat Leukemic Basophils

Maria Bachelet, Paris, France

4:40-4:50 Polymorphism in the Gene Coding for the Inducible 70kDa Heat Shock Protein HSP70 and Ovarian Cancer

Jan Jeremias, New York, New York, USA

4:50-5:00 Validity of Serum CA-125 as a Marker of Epithelial Ovarian Tumors Among Women With or Without Serum Antibodies to Chlamydia trachomatis

Jorma Paavonen, Helsinki, Finland 


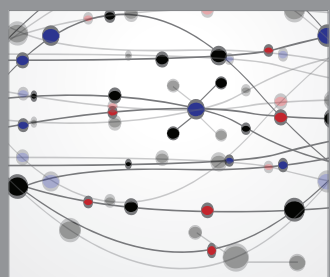

The Scientific World Journal
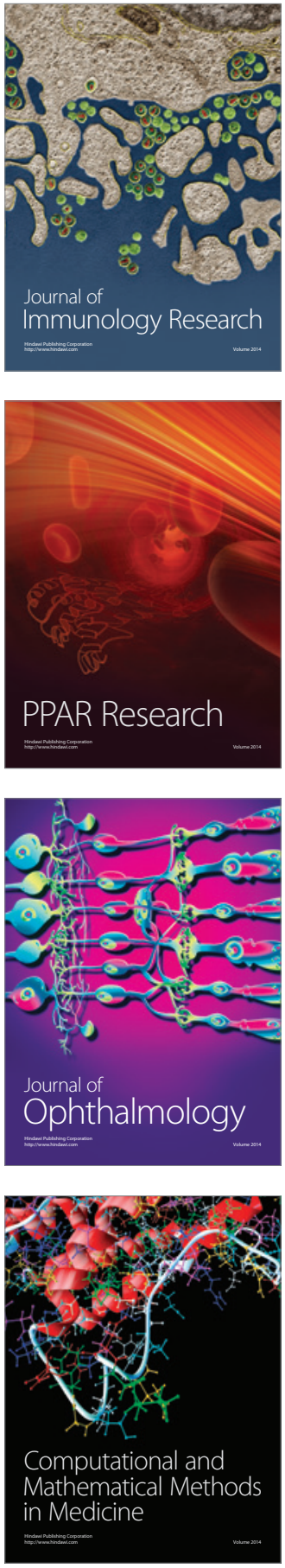

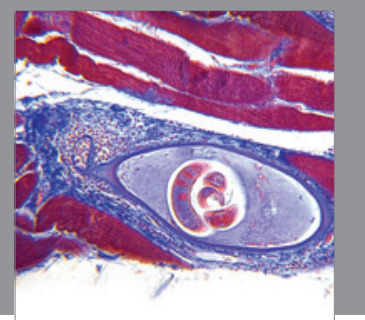

Gastroenterology

Research and Practice
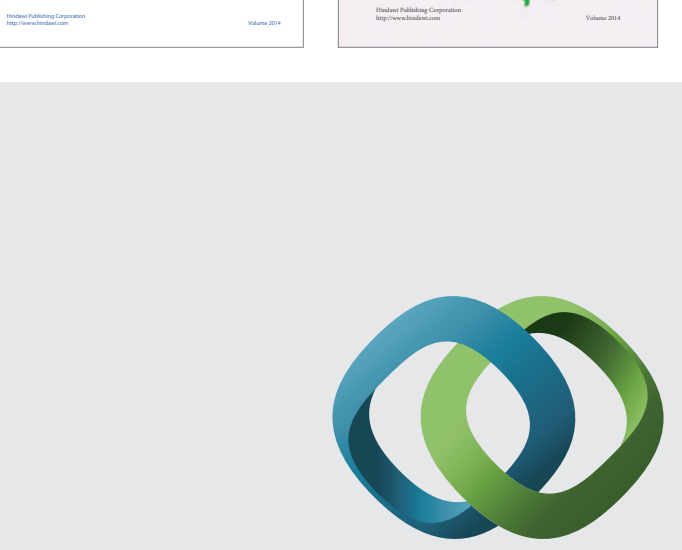

\section{Hindawi}

Submit your manuscripts at

http://www.hindawi.com
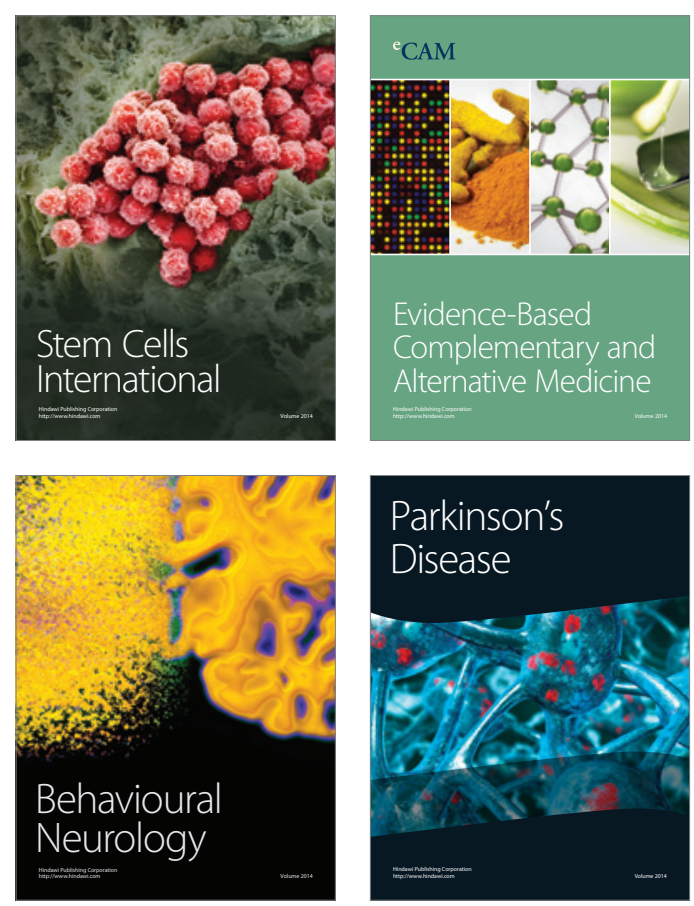

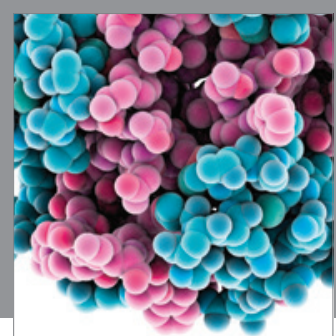

Journal of
Diabetes Research

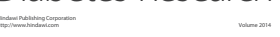

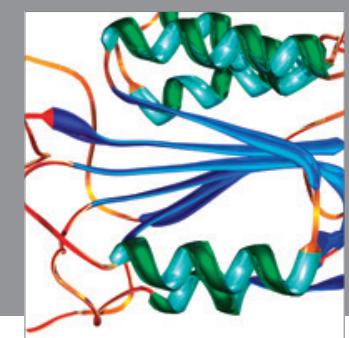

Disease Markers
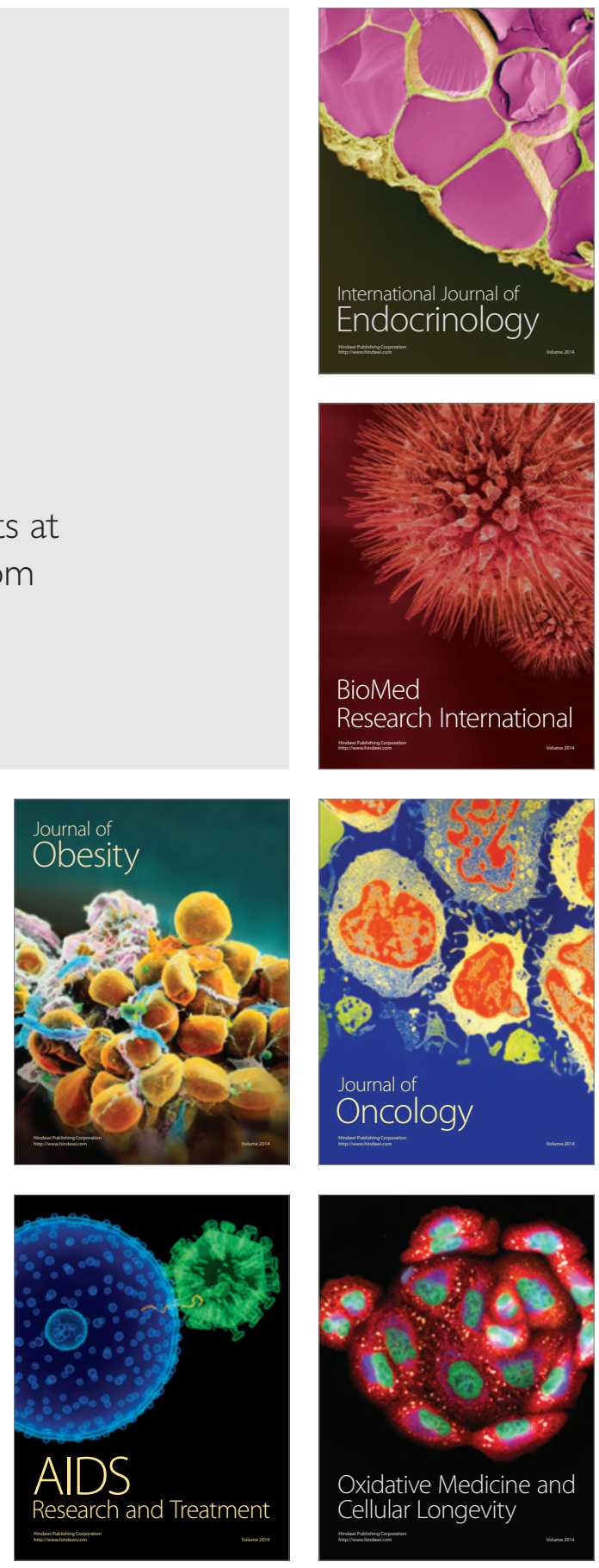